\title{
MICROPLASTIC POLLUTION ON THE STRANDLINE OF URBAN AND NATURAL CITY BEACHES: THE ROLE OF LOCAL ACTIVITIES
}

\author{
JAVIER BAYO $^{1}$, DOLORES ROJO ${ }^{1}$, SONIA OLMOS $^{1} \&$ MIRIAM LÓPEZ ${ }^{1}$ \\ ${ }^{1}$ Department of Chemical and Environmental Engineering, Technical University of Cartagena, Spain.
}

\begin{abstract}
The worldwide production of plastics has been reported to grow from 335 million $t$ in 2016 up to 348 million $t$ in 2017, giving employment to over 1.5 million people in Europe. Plastic materials have changed our way of life because of their versatility, high durability and ability to be moulded in different shapes. For that reason, when discarded in the marine environment, plastics and especially microplastics can become an environmental hazard.

This article describes the presence and abundance of microplastics in sandy beaches of a coastal city, Cartagena (southeast Spain), surrounding the Mar Menor coastal lagoon, an important tourist destination with also local activities, mainly fishery and agriculture. Microscopic observations and Fourier-transform infrared spectroscopy analyses displayed a total of 14 polymer families in the microplastic composition, mainly represented by low-density polyethylene (LDPE), high-density polyethylene, polyvinyl ester (PVE), polypropylene (PP), polystyrene, nylon (NYL) and polyester (PES). The extensive amount of polymer types together with an important variety of colours demonstrates the multiple origin of microplastics. LDPE in a film form proved to be a consequence of plastic greenhouses degradation, prone to cracking under environmental stress, because of their transportation through a northwest catchment down to the beach. Similarly, PVE used in naval composite structures as a primary resin proved to be higher in urban than in natural beaches because of the massive use of fishing boats and pleasure crafts. Littering and runoff were the main sources for other microplastic particles, mainly PP, NYL and PES.
\end{abstract}

Keywords: microlitter, microplastics, strandline, city beaches, polymers.

\section{INTRODUCTION}

The global annual production of plastics was around 335 million t for 2016, 4.03\% higher than in 2015, and it has grown up to 348 million t during 2017; this is an increase of $3.74 \%$. In Europe, the figures of annual plastic production have also revealed an increasing evolution from 60 million $t$ in 2016 up to 64.4 million $t$ in 2017 [1]. The European Commission is aiming to transform Europe into a more circular and resource-efficient economy, setting a series of ambitious targets and initiatives up to 2030 specially focussed on preventing leakage of plastics into the environment and investigating new end-of-life options for certain types of plastics waste, through a regulatory support and engagement of all stakeholders involved in the transformation [1].

The term 'microplastic' was first used by the US Air Force Materials Laboratory to describe the micro-deformation of a plastic material in response to an external force, in terms of 'Mechanisms of Microplastic Deformation' as a micromechanical property [2]. But microplastics were first described as tiny pollutants in 1972, when Carpenter and Smith [3] reported their presence on the surface of Sargasso Sea, a region of the North Atlantic Ocean without land boundaries, only defined by an ocean gyre. However, they refer to them as simply 'plastic particles', and it was not until 2004 when Thompson et al. [4] include the modern use of the term 'microplastic' to describe the small plastic pieces collected from beaches and sediments in Plymouth, United Kingdom [5]. 
Since then, several studies have identified microplastics as a ubiquitous pollutant of marine debris, because it is estimated that between 4.8 and 12.7 metric $t$ of plastic litter enters the ocean environment each year [6]. These micropollutants are of particular concern because of their ready uptake by marine organisms, including bivalves for human consumption [7], pelagic and demersal fish [8] or seafood [9], with potentially toxic adverse effects on organisms through the food web. Microplastics have the potential to accumulate both organic and inorganic pollutants, i.e. carcinogenic polychlorinated biphenyls (PCBs), polycyclic aromatic hydrocarbons (PAHs) and polybrominated diphenyl ethers as well as heavy metals [10-13]. Besides, a chemical effect has been also reported due to the release of monomers and chemical additives used in the plastic industry, i.e. plasticizers, lubricants, surfactants, antistatic, flame retardants or antioxidants [14].

The development of new petroleum-derived polymers, together with an inefficient endof-life management and the vast amount of passives accumulated in the environment over decades, makes the plastic problem complex to address, and solutions to be taken involve the responsibility of all stakeholders, including scientists, academia, society, decision-makers and industry. The Mar Menor lagoon (Fig. 1) is located in the southeast of Spain; it is a semi-enclosed coastal system connected with the Mediterranean Sea through three shallow channels, i.e. Encañizadas, El Estacio and Marchamalo. It represents one of the environments of greater biological and socio-economic value in our region and takes part in a number of protected area networks designated under regional and international agreements and European legislation [15]. As reported by Fossi et al. (2016) [16], these semi-enclosed bays accumulate pollutants to a greater degree than in open oceans, and that should be the case of microplastics. Previous studies have reported on the distribution and characteristics of toxic pollutants in the Mar Menor coastal lagoon, such as PAHs, PCBs, pesticides and pharmaceuticals [17-19], but no other papers have been devoted to the occurrence and characteristics of microplastics in this protected area.

\section{MATERIALS AND METHODS}

\subsection{The study area}

The Mar Menor is the largest coastal lagoon in Spain and one of the largest in Europe, located in the Region of Murcia (southeast Spain) (37 $49^{\prime} 10^{\prime \prime}-37^{\circ} 37^{\prime} 55^{\prime \prime} \mathrm{N}, 00^{\circ} 51^{\prime} 36^{\prime \prime}-00^{\circ} 43$ '59" W), with a surface area of $135 \mathrm{~km}^{2}$ (Fig. 1). A sand coastal barrier of $22 \mathrm{~km}$ in length, known as La Manga, closes the lagoon from the Mediterranean Sea, with natural and artificial channels that allow water exchange on either side of the sand barrier, and five islands inside the lagoon: El Barón, Perdiguera, El Sujeto, Rondella and El Ciervo.

The Mar Menor and its surroundings, islands and wetlands, comprise a designated area of 14,526.56 ha, protected under a combination of international European and Spanish environmental policies. The main threats in this area are related to agriculture, fishery, urban growth and tourist development [20]. The impacts of intensive agriculture on the lagoon are due to the nearby Campo de Cartagena plain, where traditional farming has become into intensive agriculture, with a vast majority of vegetables growing under greenhouses, an expanding tendency throughout the Mediterranean basin. The favourable climatic conditions of the region, with mild winters and high number of sunshine hours, enable vegetable production during late Autumn to early Spring [21]. Fishery is also an important activity at the Mar Menor area, due to the high quality of its products, mainly fishes and crustaceans [22]. On the other hand, 


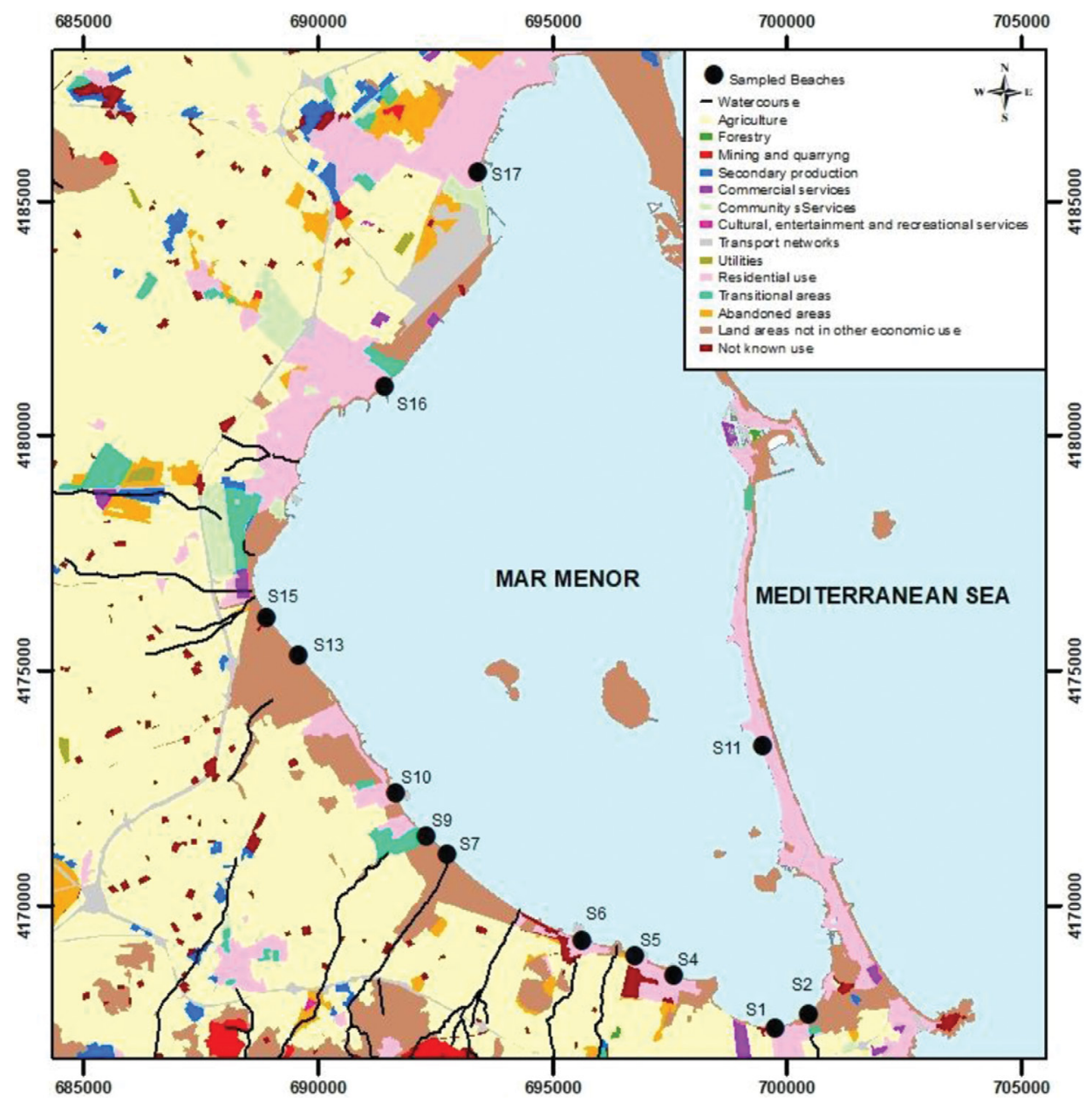

Figure 1: The Mar Menor area, including sampled beaches, watercourses and land uses.

from 1960 on, urban growing and tourist development have modified the landscape of the area, changing the orography of the shoreline with the construction of recreational ports and the enlargement of communication channels with the Mediterranean Sea [20].

\subsection{Sample collection}

Figure 1 depicts 13 sampling sites for beach sand collection, during winter 2017 and 2018 in the Mar Menor area, in order to avoid tourist season. Beaches were classified as urban, natural or semi-natural according to their degree of development, location within the urban centre and natural conservation, as presented in Table 1. Urban beaches (S1, S4, S5, S6, S10, S11, S15, S16 and S17) were those intensively used and located in the main nucleus of each municipality, with several types of commercial services and activities, and natural (S7, S13) and semi-natural (S2, S9) beaches are poorly urbanized, with relatively well-preserved natural characteristics and protection status, i.e. SPA (Special Protected Area) under EU Birds 
Table 1: Beach location and classification.

\begin{tabular}{|c|c|c|c|c|c|}
\hline Type & Sampling location & Acronym & Site code & Latitude $(\mathrm{N})$ & Longitude (W) \\
\hline \multirow[t]{9}{*}{ Urban } & Playa Honda & PHO & $\mathrm{S} 1$ & $37^{\circ} 37^{\prime} 55^{\prime \prime}$ & $00^{\circ} 44^{\prime} 11^{\prime \prime}$ \\
\hline & Mar de Cristal & MCR & $\mathrm{S} 4$ & $37^{\circ} 38^{\prime} 33^{\prime \prime}$ & $00^{\circ} 45^{\prime} 38^{\prime \prime}$ \\
\hline & Islas Menores & IME & S5 & $37^{\circ} 38^{\prime} 47^{\prime \prime}$ & $00^{\circ} 46^{\prime} 11^{\prime \prime}$ \\
\hline & Los Nietos & LNI & S6 & $37^{\circ} 38^{\prime} 58^{\prime \prime}$ & $00^{\circ} 46^{\prime} 57^{\prime \prime}$ \\
\hline & Los Urrutias & LUR & $\mathrm{S} 10$ & $37^{\circ} 40^{\prime} 43^{\prime \prime}$ & $00^{\circ} 49^{\prime} 36^{\prime \prime}$ \\
\hline & $\begin{array}{l}\text { La Manga del Mar } \\
\text { Menor }\end{array}$ & MMM & S11 & $37^{\circ} 41^{\prime} 10^{\prime \prime}$ & $00^{\circ} 44^{\prime} 16^{\prime \prime}$ \\
\hline & $\begin{array}{l}\text { Marina del Carmolí } \\
\text { Litoral Norte }\end{array}$ & MCLN & S15 & $37^{\circ} 42^{\prime} 46^{\prime \prime}$ & $00^{\circ} 51^{\prime} 24^{\prime \prime}$ \\
\hline & Los Narejos & LNR & S16 & $37^{\circ} 45^{\prime} 24^{\prime \prime}$ & $00^{\circ} 49^{\prime} 37^{\prime \prime}$ \\
\hline & $\begin{array}{l}\text { Santiago de la } \\
\text { Ribera }\end{array}$ & SRB & S17 & $37^{\circ} 47^{\prime} 50^{\prime \prime}$ & $00^{\circ} 48^{\prime} 12^{\prime \prime}$ \\
\hline \multirow[t]{2}{*}{ Semi-natural } & Playa Paraíso & PPA & $\mathrm{S} 2$ & $37^{\circ} 38^{\prime} 04^{\prime \prime}$ & $00^{\circ} 43^{\prime} 41^{\prime \prime}$ \\
\hline & Playa La Perla & PPE & S9 & $37^{\circ} 40^{\prime} 13^{\prime \prime}$ & $00^{\circ} 49^{\prime} 10^{\prime \prime}$ \\
\hline \multirow[t]{2}{*}{ Natural } & $\begin{array}{l}\text { Saladar Lo Poyo } \\
\text { Litoral }\end{array}$ & SPL & S7 & $37^{\circ} 40^{\prime} 00^{\prime \prime}$ & $00^{\circ} 48^{\prime} 52^{\prime \prime}$ \\
\hline & $\begin{array}{l}\text { Marina del Carmolí } \\
\text { Litoral Sur }\end{array}$ & MCLS & $\mathrm{S} 13$ & $37^{\circ} 42^{\prime} 20^{\prime \prime}$ & $00^{\circ} 50^{\prime} 58^{\prime \prime}$ \\
\hline
\end{tabular}

Directive (79/409/EEC), SCI (Site of Community Importance) under the EU Habitats Directive (92/43/EEC) and SPAMI (Special Protected Area of Mediterranean Interest) within the Barcelona Convention for the Protection of the Mediterranean Sea, among others.

Replicate samples were collected and placed into 120-mm glass Petri dishes, with the aid of a metal trowel an a square of $0.50 \mathrm{~m}$ length (Fig. 2). An average amount ( \pm standard error of the mean) of $186.1 \pm 8.1 \mathrm{~g}$ of sand was collected for each sample. As in previous studies

(a)

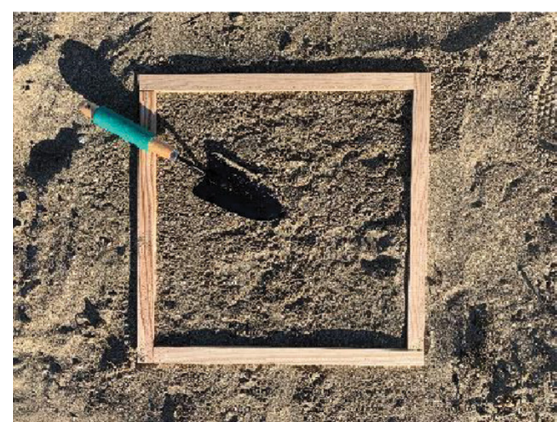

(b)

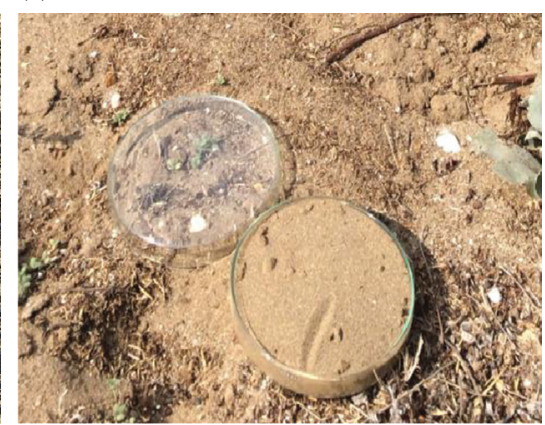

Figure 2: Sample collection: (a) square of $0.5 \mathrm{~m}$ length; (b) sample collected in a 120-mm glass Petri dish. 
[14,23], the use of plastic laboratory devices was limited to the maximum, always using cotton gowns and nitrile gloves in all extraction processes. Besides, laboratory material was cleaned with isopropyl alcohol and bidistilled water. [23]

\subsection{Sample processing and analysis}

Once in our laboratory (Fig. 3), samples were dried overnight in an oven at $80^{\circ} \mathrm{C}$ to constant weight and then sieved on a 5-mm mesh sieve. Microlitre, and of course microplastics, in the sieved fraction was collected by means of 0.51 of a concentrated sodium chloride solution [NaCl; $\left.120 \mathrm{~g} \cdot \mathrm{l}^{-1}\right]$, placing the mixture into a 21 glass beaker with mechanical stirring for 20 min. Supernatant with floating particles was filtered through a paper membrane filter $(0.45$ $\mu \mathrm{m}$ pore size). After washing this filter with bidistilled water and drying on an air-forced stove, microparticles were ready for microscopic and Fourier-transform infrared spectroscopy (FTIR) analyses.

Possible microplastic particles were examined under an Olympus SZ-61TR Zoom Trinocular Microscope (Olympus Co., Tokyo, Japan), providing a superior image quality with a $10^{\circ}$ convergence angle at a working distance of $110 \mathrm{~mm}$, with magnification ranging from $6.7 \times$ to $45 \times$ and LED lighting. This trinocular microscope was coupled to a Leica MC190 HD digital camera, with a maximum resolution of $1,596 \times 1,196$ pixels, 10 bits per colour
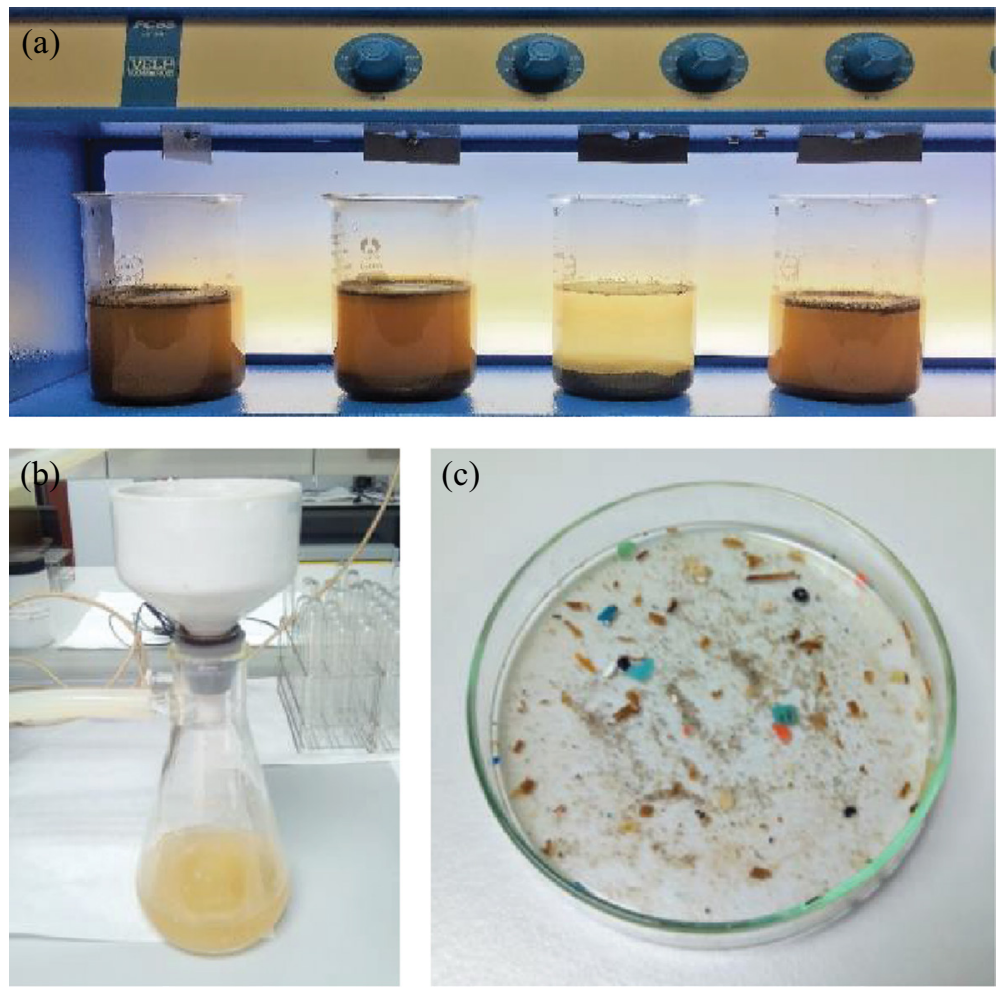

Figure 3: Sample processing: (a) mechanical stirring in a jar-test device; (b) vacuum filtration through a paper membrane filter; (c) isolation of microlitre. 
channel, 7.5 frames per second at full resolution and $0.1 \mathrm{~ms}$ to $1 \mathrm{~s}$ exposure time. The infrared spectra were acquired with a Thermo Nicolet 5700 FTIR spectrometer (Thermo Nicolet Analytical Instruments, Madison, WI, USA), provided with a deuterated triglycine sulfate (DTGS) detector and $\mathrm{KBr}$ detector. The spectra collected were an average of 20 scans with a resolution of $16 \mathrm{~cm}^{-1}$ in the range of $4,000-400 \mathrm{~cm}^{-1}$. Spectra were controlled and evaluated by the OMNIC software package, by means of a reference polymer library containing spectra of all common polymers, together with literature [24]. Data were processed with the SPSS (Statistic Package for Social Science) 26.0 software. Concentrations were expressed as microlitre (ML) or microplastics (MP) per kilogram of dry beach sand.

\section{RESULTS AND DISCUSSION}

\subsection{General results}

A total of 554 microlitre particles were isolated from sand of 13 sampled beaches, with an average concentration of $95.2 \pm 9.7 \mathrm{ML} \mathrm{kg}^{-1}$, and maximum and minimum values correspond to 10.6 and 275.6 $\mathrm{ML} \mathrm{kg}^{-1}$, for two samples collected in S13 and S10, respectively. A statistically significant difference was observed between average concentration of microlitre collected in 2017 (121.6 $\left.\pm 14.4 \mathrm{ML} \mathrm{kg}^{-1}\right)$ versus 2018 (68.7 $\left.\pm 9.1 \mathrm{ML} \mathrm{kg}^{-1}\right)($ F-Snedecor $=$ $9.670, p=0.004)$, indicating an improvement in beach sand quality. Microplastics accounted for $47.5 \%$ of microlitre, as revealed by FTIR analysis, with an average concentration of 43.5 $\pm 7.2 \mathrm{MP} \mathrm{kg}^{-1}$, and total absence in a sample collected in S1 during 2018. The maximum concentration was for a sample collected in S10, $166.3 \mathrm{MP} \mathrm{kg}^{-1}$, the same sample with the highest microlitre concentration previously indicated. However, no statistically significant differences were observed between samples collected in 2017 and 2018 ( $F$-Snedecor $=0.029$, $p=0.865$ ). We would like to emphasize that without an appropriate identification technique, i.e. FTIR, non-plastic microparticles could be easily counted as microplastics, thus overestimating their abundance. Figure 4 depicts two images of (a) microplastic and (b) non-plastic microlitre, isolated in samples S10 and S5, respectively, in order to prove their similarity for a naked eye.

The average concentration of microplastics reported in our study was higher than that reported by Nor and Obbard (2014) [25] in Singapore's coastal mangrove ecosystems, i.e. $36.8 \pm 23.6$ particles per $\mathrm{kg}$ dry sediment, with a maximum concentration of $62.7 \pm 27.2$
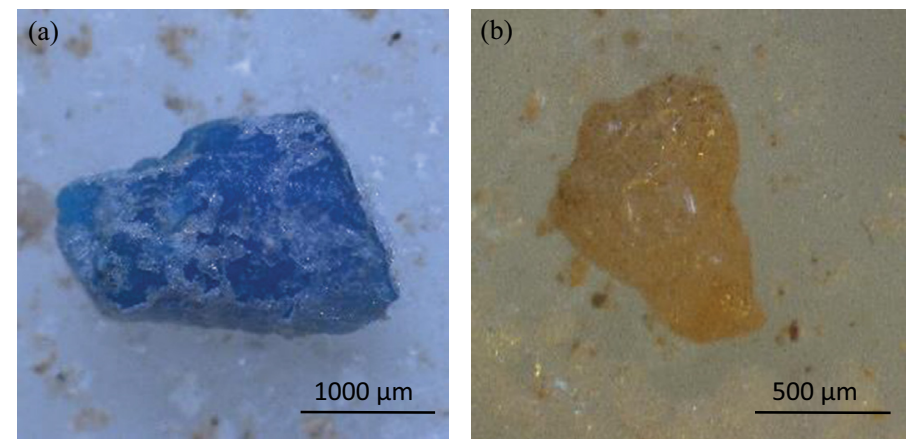

Figure 4: Microlitre and microplastics: (a) polypropylene (PP) (S10); (b) calcium carbonate (S5). 


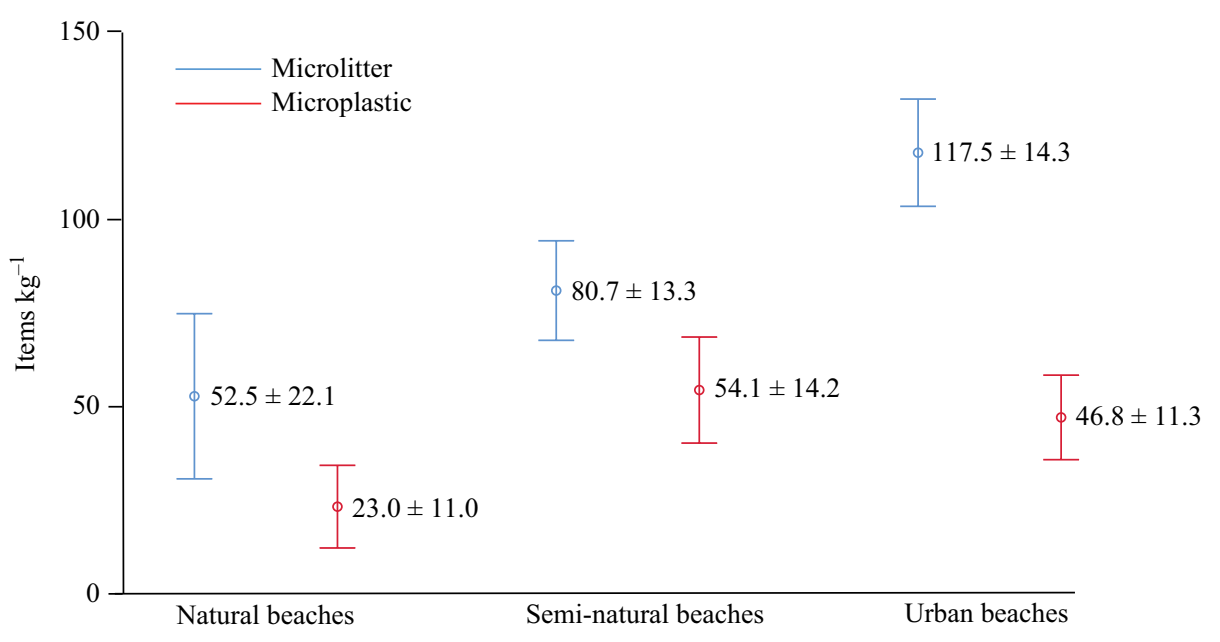

Figure 5: Average concentrations of microlitre and microplastics in natural, semi-natural and urban beaches (error bars represent standard error of the mean).

particles per kg dry sediment. Conversely, the concentration of microplastics in the Mar Menor beach sand was lower than the lowest average value reported by Yu et al. (2016) [26] in an inner sea of China $\left(102.9 \pm 39.9\right.$ items $\left.\mathrm{kg}^{-1}\right)$.

The one-way ANOVA analysis demonstrated no statistically significant differences on microlitre $(F$-Snedecor $=3.644, p=0.041)$ or microplastic $(F$-Snedecor $=0.970, p=0.393)$ concentrations among natural, semi-natural or urban beaches, despite an increase on average values for microlitre and a slight increase of microplastics in semi-natural beaches, as presented in Fig. 5.

The use of the stereomicroscope allowed a more exhaustive classification according to the shape of microplastics, with fragments being the most recurrent form $(66.9 \%)$, followed by films and fibres (12.5\%), spherules (6.6\%) and foam (1.6\%), as depicted in Fig. 6. The average concentrations were $29.9 \pm 5.7$ items $\mathrm{kg}^{-1}$ for fragments, $6.1 \pm 2.7$ items $\mathrm{kg}^{-1}$ for films, $5.3 \pm 1.7$ items kg-1 for fibres, $2.8 \pm 0.9$ items kg${ }^{-1}$ for spherules and $0.6 \pm 0.4$ items kg$~^{-1}$ for foam. The fragmented forms of microplastics are linked to the transformation of macro- and mesoplastics, so we can state that most of them are secondary microplastics. The percentage of fragments was quite similar to that reported by Sul et al. (2009) [27] in sand from 11 beaches of Fernando de Noronha (Equatorial Western Atlantic) (65\%), being the unique type of item sampled on both sides of the island, and Hidalgo-Ruz and Thiel (2013) [28] indicated $89 \%$ of fragments on Chilean beaches, except for a beach where $94 \%$ were spherules or pellets. In our study, there were no statistically significant differences among beach types for any of the five forms isolated, although spherules and foam were never detected in natural beaches. The main colours for microplastics were beige $(31.1 \%)$, white $(16.0 \%)$, blue $(12.1 \%)$, brown $(8.6 \%)$ and orange $(7.8 \%)$.

The lowest size corresponded to a pink spherule isolated in $\mathrm{S} 4(120 \mu \mathrm{m})$, with the average size for all microplastics collected being $1.4 \pm 0.1 \mathrm{~mm}$. Northwest samples (S7, S9, S10, $\mathrm{S} 13, \mathrm{~S} 15, \mathrm{~S} 16$ and S17) displayed a statistically significant higher average size $(2.0 \pm 0.2$ $\mathrm{mm})$ than southeast samples (S1, S2, S4, S5, S6 and S11) $(1.1 \pm 0.1 \mathrm{~mm})(F-$ Snedecor $=$ $21.340, p=0.000)$. As depicted in Fig. 7 , this study also revealed that the highest microplastic 


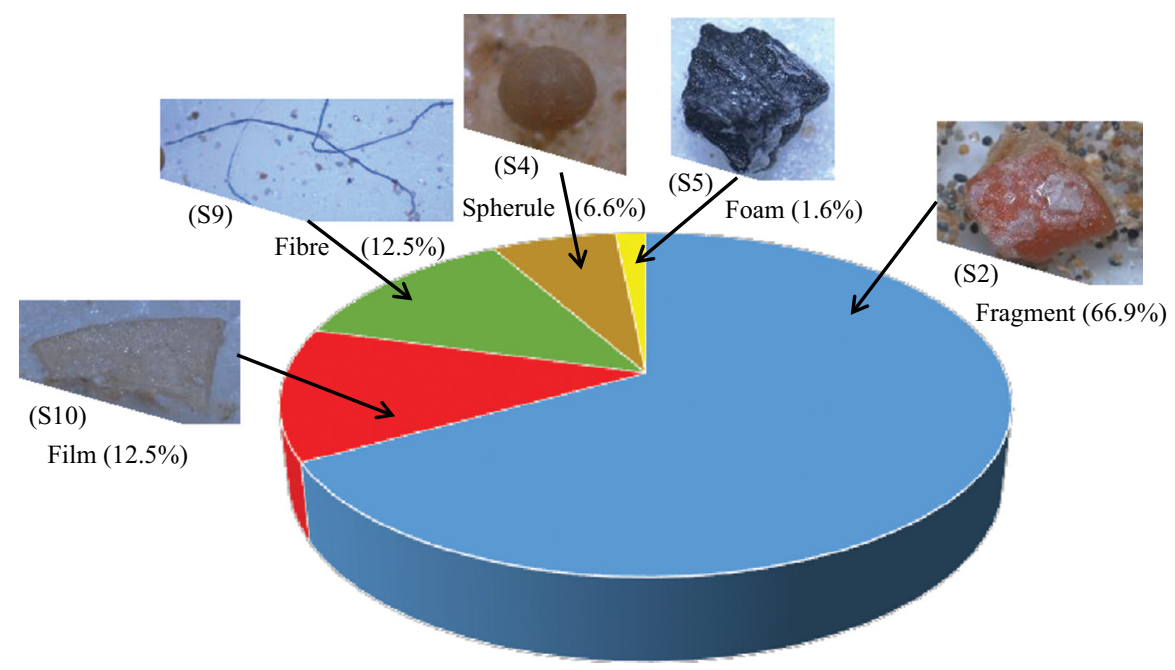

Figure 6: Main forms isolated in beach sand samples.

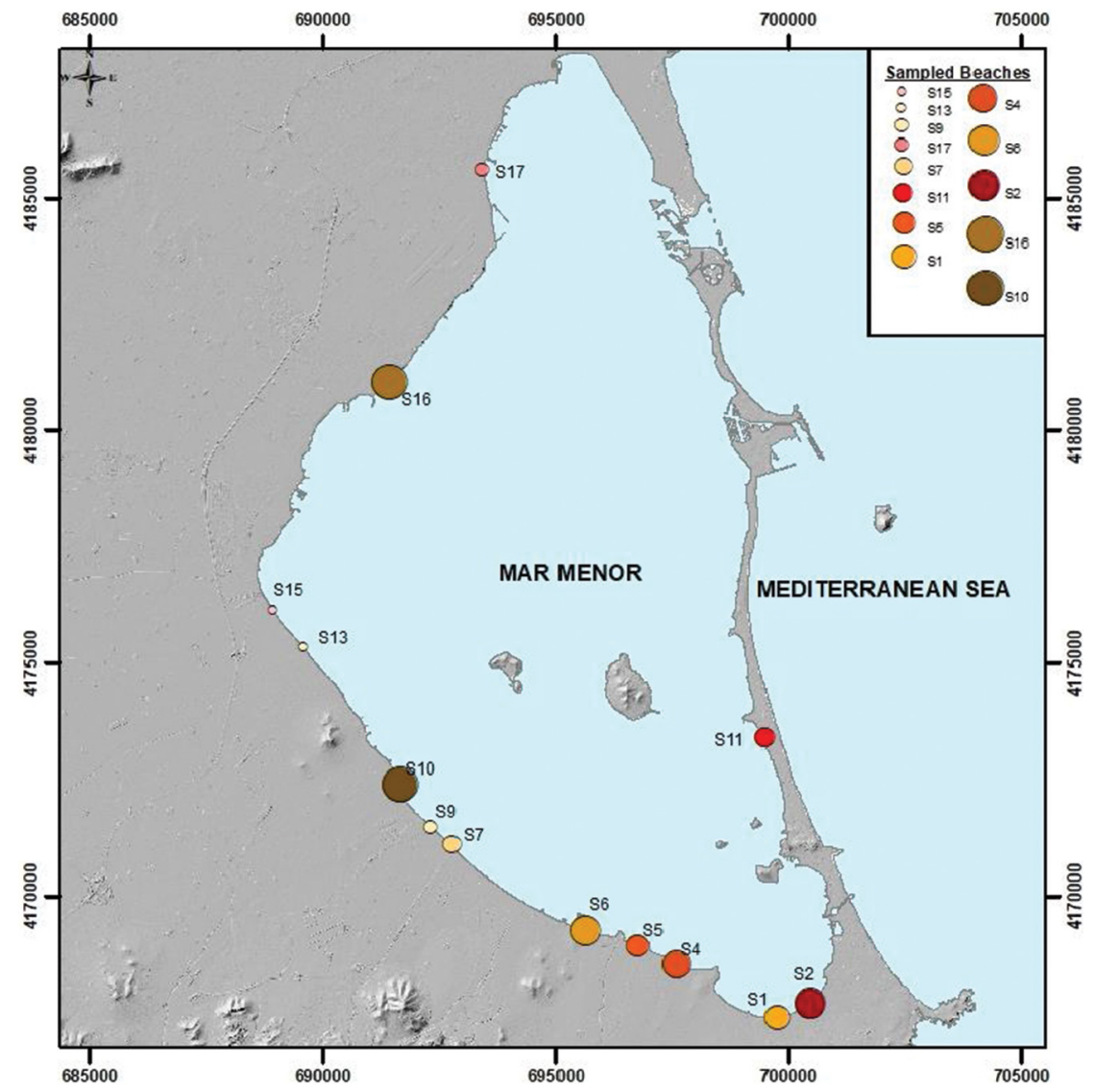

Figure 7: Microplastic average concentrations in 13 sampled beaches. 
concentrations were detected in two northwest samples, i.e. S10 (166.3 items $\left.\mathrm{kg}^{-1}\right)$ and S16 $\left(113.8\right.$ items $\left.\mathrm{kg}^{-1}\right)$. This area is characterized by covering the drainage of $83.4 \%$ of watercourses from land-use runoff drains affecting the lagoon, a fact that will be further discussed.

In relation to plastic polymers, a total of 14 polymer families were isolated in beach sand samples, mainly represented by low-density polyethylene (LDPE) with $17.2 \pm 5.1$ items $\mathrm{kg}^{-1}$, followed by polyvinyl ester (PVE) with $8.6 \pm 4.0$ items $\mathrm{kg}^{-1}$, high-density polyethylene (HDPE) with $6.3 \pm 1.8$ items kg-1, polypropylene (PP) with $3.2 \pm 1.5$ items kg-1, polystyrene (PS) with $1.4 \pm 0.6$ items $\mathrm{kg}^{-1}$ and polyester (PES) with $1.1 \pm 0.6$ items $\mathrm{kg}^{-1}$.

\subsection{The influence of local activities}

The fact that the highest microplastic concentrations were observed in two northwest samples, i.e. S10 (166.3 items $\mathrm{kg}^{-1}$ ) and S16 (113.8 items $\mathrm{kg}^{-1}$ ), previously related to runoff, could be associated to an extensive use of sludge from wastewater treatment plants, which are receptors for the cumulative loading of microplastics, with the vast majority becoming entrained in the sewage sludge [29]. However, despite this, no statistically significant differences were observed between microplastic concentrations in northwest and southeast samples, indicating that also local activities must play an important role as microplastic pollution sources. This hypothesis is highlighted by the fact that the highest and the lowest microplastic pollution samples were located in two northwest beaches, i.e. S10 (166.3 items $\left.\mathrm{kg}^{-1}\right)$ and S15 (8.2 items $\mathrm{kg}^{-1}$ ), both of them located over the discharge of Rambla del Albujón and El Beal, the main watercourses in the western part of the coastal lagoon that become especially fierce during flash flood events. Human activities carried out in S10, mainly fishing activities, urban development and tourism, may contribute to these different patterns of microplastic accumulation.

Also, the extensive amount of polymer families identified in our study should be related to the geographical position of the coastal lagoon, acting as a sink of a great variety of plastic debris together with the enormous environmental passives built during the last 50 years. Previous studies in other beaches have identified a number of different polymers lower than those reported in this study, i.e. Lots et al. (2017) [30] that identified only three types of polymer in European beach sediments: PES, PP and polyethylene. Competent authorities responsible for cleaning beaches cannot tackle with the elimination of these microparticles, so other alternatives to the use of plastic should be addressed, with new materials and designs that prevent different polymers from reaching the environment. In addition, it is necessary to implement educational programs and new legislative measures. The case of LDPE is significant, as it is widely used for packing materials and plastic carrier bags, being a high potential precursor for microplastics [31]. Not many studies identify LDPE as the dominant type of polymer in environmental samples. However, it is a common polymer in lake sediments, as reported by Imhoff et al. (2013) [32] and Sruthy and Ramasamy (2017) [33], and is the most dominant type of microplastic in six out of ten of sampling points selected for the study. Indeed, we could prove that $71.9 \%$ of film forms were made of LDPE. The use of greenhouses in agricultural soils of Campo de Cartagena, located in the northwest part of the lagoon, could be also an important source of these LDPE films. The ageing and fragmentation of plastic greenhouses because of the synergistic effect of tensile stress, UV radiation and temperature reported by different authors [34,35], together with wind and runoff transportation of these microplastic films, could explain these results. In fact, the concentration of microplastic films in northwest samples $\left(11.0 \pm 6.2\right.$ items $\left.\mathrm{kg}^{-1}\right)$ proved to be higher than the concentration in 
southeast samples $\left(2.4 \pm 0.8\right.$ items $\left.\mathrm{kg}^{-1}\right)$, although without statistically significant differences ( $F$-Snedecor $=2.518, p=0.125)$. The presence of PVE resins, increasingly used as the matrix for fibre-reinforced composites in marine structures [36], was higher in urban beaches (14.6 \pm 7.3 items kg-1 $)$ than in semi-natural $\left(0.5 \pm 0.5\right.$ items $\left.\mathrm{kg}^{-1}\right)$ or natural $\left(1.8 \pm 1.8\right.$ items $\left.\mathrm{kg}^{-1}\right)$ beaches, although also without statistically significant differences $(F$-Snedecor $=1.445, p=$ $0.255)$.

\section{CONCLUSIONS}

In this article, the abundance and concentration of microplastics in beach sand has proved to be related to environmental factors and anthropogenic actions. Microplastics represented $47.5 \%$ of total microlitre isolated in 13 sampling beaches surrounded by the Mar Menor coastal lagoon, located in the southeast of Spain, with an average concentration of $43.5 \pm$ 7.2 $\mathrm{MP} \mathrm{kg}^{-1}$, with the highest microplastic concentrations detected in two northwest samples. This northwest area is characterized by covering the drainage of $83.4 \%$ of watercourses from land-use runoff drains affecting the lagoon, and it is the place where the agricultural soils of Campo de Cartagena are located, with a massive use of sludge from wastewater treatment plants as a fertilizer. Although total microlitre proved to decrease from 2017 to 2018, no statistically significant differences could be observed for microplastic concentrations. Fragments were the most isolated form (66.9\%), followed by films and fibres $(12.5 \%)$, spherules $(6.6 \%)$ and foam (1.6\%). The main colours for microplastics were beige $(31.1 \%)$, white $(16.0 \%)$, blue $(12.1 \%)$, brown $(8.6 \%)$ and orange $(7.8 \%)$, and the average size for all microplastics collected was $1.4 \pm 0.1 \mathrm{~mm}$. The dominant polymer type was LDPE, followed by PVE, HDPE, PP, PS and PES. LDPE concentrations should be related to the wide use of that polymer type together with the breakage of plastic greenhouses, as the concentration of film forms proved also to be higher in northwest samples. PVE microplastics could be linked to fishery activities, because of the use of that polymer in naval composite structures, where the environment is highly corrosive.

\section{ACKNOWLEDGEMENTS}

Analyses carried out by S. Olmos were supported by a grant from Fundación Séneca (20268/ FPI/17). Authors acknowledge technical and financial support from Contesma \& Comprotec (Dr. Pedro Martínez-Baños).

\section{REFERENCES}

[1] Plastics - the Facts 2018. An analysis of European plastics production, demand and waste data, www. plasticseurope.org/application/files/6315/4510/9658/Plastics_the_ facts_2018_AF_web.pdf (accessed 03 May 2019).

[2] Ingram, A.G., Hoskins, J.H., Sovik, J.H., Maringer, R.E. \& Holden, F.C., Study of microplastic properties and dimensional stability of materials. Technical Report AFMLTR-67-232, Part II. United States Air Force Materials Laboratory, 1968.

[3] Carpenter, E.J. \& Smith, K.L., Plastics on the Sargasso Sea surface. Science, 175(4027), pp. 1240-1241, 1972.

[4] Thompson, R.C., Olsen, Y., Mitchell, R.P., Davis, A., Rowland, S.J., John, A.W.G., McGonigle, D. \& Russell, A.E., Lost at sea: where is all the plastic? Science, 304(5672), pp. 838-838, 2004.

[5] Crawford, C.B. \& Quinn, B., Microplastics Pollutants, Elsevier: Amsterdam, pp. 101130, 2017. 
[6] Miller, M.E., Kroon, F.J. \& Motti, C.A., Recovering microplastics from marine samples: A review of current practices. Marine Pollution Bulletin, 123(1-2), pp. 6-18, 2017.

[7] Van Cauwenberghe, L. \& Janssen, C.R., Microplastics in bivalves cultured for human consumption. Environmental Pollution, 193, pp. 65-70, 2014.

[8] Lusher, A.L., McHugh, M. \& Thompson, R.C., Occurrence of microplastics in the gastrointestinal tract of pelagic and demersal fish from the English Channel. Marine Pollution Bulletin, 67(1-2), pp. 94-99, 2013.

[9] Dehaut, A., Cassone, A.L., Frère, L., Hermabessiere, L., Himber, C., Rinnert, E., Rivière, G., Lambert, C., Soudant, P., Huvet, A., Duflos, G. \& Paul-Pont, I., Microplastics in seafood: benchmark protocol for their extraction and characterization. Environmental Pollution, 215, pp. 223-233, 2016.

[10] Hüffer, T. \& Hofmann, T., Sorption of non-polar organic compounds by micro-sized plastic particles in aqueous solution. Environmental Pollution, 214, pp. 194-201, 2016.

[11] Bayo, J., Martínez, A., Guillén, M., Olmos, S., Roca, M.J. \& Alcolea, A., Microbeads in commercial facial cleansers: threatening the environment. Clean-Soil, Air, Water, 45(7), pp. 1-11, 2017.

[12] Bayo, J., Guillén, M., Olmos, S., Jiménez, P., Sánchez, E. \& Roca, M.J., Microplastics as vector for persistent organic pollutants in urban effluents: The role of polychlorinated biphenyls. International Journal of Sustainable Development and Planning, 13(4), pp. 671-682, 2018.

[13] Liu, G., Zhu, Z., Yang, Y., Sun, Y., Yu, F. \& Ma, J. Sorption behavior and mechanism of hydrophilic organic chemicals to virgin and aged microplastics in freshwater and seawater. Environmental Pollution, 246, pp. 26-33, 2019.

[14] Bayo, J., Olmos, S. \& López-Castellanos, Non-polymeric chemicals or additives associated with microplastic particulate fraction in a treated urban effluent. WIT Transactions on The Built Environment, 179, pp. 303-314, 2018.

[15] Robledano, F., Esteve, M.A., Calvo, J.F., Martínez-Paz, J.M., Farinós, P., Carreño, M. F., Soto, I., Avilés, M., Ballesteros, G.A., Martínez-Baños, P. \& Zamora, A., Multicriteria assessment of a proposed ecotourism, environmental education and research infrastructure in a unique lagoon ecosystem: The Encañizadas del Mar Menor (Murcia, SE Spain). Journal for Nature Conservation, 43, pp. 201-210, 2018.

[16] Fossi, M.C., Marsili, L., Baini, M., Giannetti, M., Coppola, D., Guerranti, C., Caliani, I., Minutoli, R., Lauriano, G., Finoia, M.G., Rubegni, F., Panigada, S., Bérubé, M., Ramírez, J.U. \& Panti, C., Fin whales and microplastics: The Mediterranean Sea and the Sea of Cortez scenarios. Environmental Pollution, 209, pp. 68-78, 2016.

[17] Moreno-González, R., Campillo, J.A. \& León, V.M., Influence of an intensive agricultural drainage basin on the seasonal distribution of organic pollutants in seawater from a Mediterranean coastal lagoon (Mar Menor, SE Spain). Marine Pollution Bulletin, 77, pp. 400-411, 2013.

[18] Moreno-González, R., Rodríguez-Mozaz, S., Gros, M., Pérez-Cánovas, E., Barceló, D. \& León, V.M., Input of pharmaceuticals through coastal surface watercourses into a Mediterranean lagoon (Mar Menor, SE Spain): sources and seasonal variations. The Science of the Total Environment, 490, pp. 59-72, 2014.

[19] Carratalá, A., Moreno-González, R. \& León, V., Occurrence and seasonal distribution of polycyclic aromatic hydrocarbons and legacy and current-use pesticides in air from a Mediterranean coastal lagoon (Mar Menor, SE Spain). Chemosphere, 167, pp. 382 395, 2017. 
[20] Conesa, H.M. \& Jiménez-Cárceles, F.J., The Mar Menor lagoon (SE Spain): A singular natural ecosystem threatened by human activities. Marine Pollution Bulletin, 54, pp. 839-849, 2007.

[21] Fernandez, M.D., Gallardo, M., Bonachela, S., Orgaz, F., Thompson, R.B. \& Fereres, E., Water use and production of a greenhouse pepper crop under optimum and limited water supply. The Journal of Horticultural Science and Biotechnology, 80(1), pp. 8796, 2005.

[22] Pérez-Ruzafa, A., Navarro, S., Barba, A., Marcos, C., Cámara, M.A., Salas, F. \& Gutiérrez, J.M., Presence of pesticides throughout trophic compartments of the food web in the Mar Menor Lagoon (SE Spain). Marine Pollution Bulletin, 40(2), pp. 140-151, 2000.

[23] Rocha-Santos, T. \& Duarte, A.C., A critical overview of the analytical approaches to the occurrence, the fate and the behavior of microplastics in the environment. TrAC Trends in Analytical Chemistry, 65, pp. 47-53, 2015.

[24] Hummel, D.O., Atlas of Plastics Additives: Analysis by Spectrometric Methods, Springer: Berlin/Heidelberg, pp. 537, 2002.

[25] Nor, N.H.M. \& Obbard, J.P., Microplastics in Singapore's coastal mangrove ecosystems. Marine Pollution Bulletin, 79(1-2), pp. 278-283, 2014.

[26] Yu, X., Peng, J., Wang, J., Wang, K. \& Bao, S., Occurrence of microplastics in the beach sand of the Chinese inner sea: The Bohai Sea. Environmental Pollution, 214, pp. 722-730, 2016.

[27] do Sul, J.A., Spengler, Â. \& Costa, M.F., Here, there and everywhere. Small plastic fragments and pellets on beaches of Fernando de Noronha (Equatorial Western Atlantic). Marine Pollution Bulletin, 58(8), pp. 1236-1238, 2009.

[28] Hidalgo-Ruz, V. \& Thiel, M., Distribution and abundance of small plastic debris on beaches in the SE Pacific (Chile): a study supported by a citizen science project. Marine Environmental Research, 87, pp. 12-18, 2013.

[29] Mahon, A.M., O'Connell, B., Healy, M.G., O'Connor, I., Officer, R., Nash, R. \& Morrison, L., Microplastics in sewage sludge: effects of treatment. Environmental Science \& Technology, 51(2), pp. 810-818, 2016.

[30] Lots, F.A., Behrens, P., Vijver, M.G., Horton, A.A. \& Bosker, T., A large-scale investigation of microplastic contamination: Abundance and characteristics of microplastics in European beach sediment. Marine Pollution Bulletin, 123(1-2), pp. 219-226, 2017.

[31] Dümichen, E., Barthel, A.K., Braun, U., Bannick, C.G., Brand, K., Jekel, M. \& Senz, R., Analysis of polyethylene microplastics in environmental samples, using a thermal decomposition method. Water Research, 85, pp. 451-457, 2015.

[32] Imhof, H.K., Ivleva, N.P., Schmid, J., Niessner, R. \& Laforsch, C., Contamination of beach sediments of a subalpine lake with microplastic particles. Current Biology, 23(19), pp. R867-R868, 2013.

[33] Sruthy, S. \& Ramasamy, E.V., Microplastic pollution in Vembanad Lake, Kerala, India: the first report of microplastics in lake and estuarine sediments in India. Environmental Pollution, 222, pp. 315-322, 2017.

[34] Briassoulis, D., The effects of tensile stress and the agrochemical Vapam on the ageing of low density polyethylene (LDPE) agricultural films. Part I. Mechanical behaviour. Polymer Degradation and Stability, 88(3), pp. 489-503, 2005. 
[35] Feuilloley, P., Cesar, G., Benguigui, L., Grohens, Y., Pillin, I., Bewa, H., Lefaux, S. \& Jamal, M., Degradation of polyethylene designed for agricultural purposes. Journal of Polymers and the Environment, 13(4), pp. 349-355, 2005.

[36] Pantano, V., Compston, P., Stachurski, Z.H. \& Jar, P.Y., Effect of matrix toughness on the shear strength of brittle and rubber-modified glass-fiber/vinyl ester composites. Journal of Materials Science Letters, 21(10), pp. 771-773, 2002. 